\title{
Prevalence of Subclinical Mastitis in Cows: In and Around Nagpur Region
}

\author{
M. S. Lahamge ${ }^{1}$, A. Thakre ${ }^{2}$, S. W. Bonde ${ }^{1 *}$, S. D. Borkar ${ }^{1}$, \\ A. P. Somkuwar ${ }^{3}$ and D. V. Patil ${ }^{4}$ \\ ${ }^{1}$ Department of Veterinary Biochemistry, ${ }^{2}$ Department of Veterinary Physiology, \\ ${ }^{3}$ Department of Veterinary Pharmacology and Toxicology, \\ ${ }^{4}$ Department of Animal Genetics and Breeding, Nagpur Veterinary College, Nagpur, \\ Maharashtra Animal and Fishery Sciences University, Nagpur 440001, India
}

*Corresponding author

\section{A B S T R A C T}

\section{Keywords}

Cow, Modified

California mastitis

test, Prevalence,

Subclinical mastitis

Article Info

Accepted:

04 November 2019

Available Online:

10 December 2019
The study was conducted to determine the prevalence of subclinical mastitis in cows in and around the Nagpur region on the basis of Modified California Mastitis Test (MCMT). A total 601 milk samples from 151 cows were screened by Modified California Mastitis Test for identification of subclinical mastitis. Out of 601 milk samples, about 200 milk samples were positive for subclinical mastitis while 390 milk samples observed to normal. About 83 milk samples were observed as '+', 69 samples as ' ++ ' and 48 samples as ' +++ ' out of 200 subclinically affected milk samples. The overall animal wise and quarter wise prevalence of subclinical mastitis on the basis of CMT was $70.19 \%$ and $34.94 \%$, respectively. The quarter wise $34.94 \%$ milk samples were found positive for subclinical mastitis while $65.06 \%$ milk samples were found negative. From all samples $13.81 \%, 11.48 \%$ and $7.99 \%$ milk samples were observed for '+', ' ++ ' and ' +++ ', respectively.

\section{Introduction}

Mastitis is one of the economically important and most expensive diseases of dairy cattle among all production disease (Bhikane and Kawitkar, 2016). This disease responsible for spread of different harmful zoonotic disease to humans such as Brucellosis, Tuberculosis, Salmonellosis etc. (Shukla et al., 1998). Mastitis is lactation associated disease with inflammation of parenchyma of mammary gland. There are about 140 microbial species and sub-species responsible for causing udder infection (Constable et al., 2017). It is 
responsible for physical and chemical changes in milk and pathological changes in tissue udder (Sharma, 2007; Constable et al., 2017). Mastitis is classified into two form clinical and subclinical form. Clinical mastitis is occurrence of infection by sudden onset, alteration in composition and appearance of milk; reduce milk production and signs of local inflammation in affected mammary quarters. In other hand, Subclinical mastitis is occurrence of infection without clear signs of local inflammation or systemic involvement. In SCM no visible signs are present in the milk and on the udder, but decrease milk production. This form of disease is most widespread and prevalent than that of clinical mastitis (Hillerton, 1998; Kader et al., 2003, Abebe et al., 2016). Subclinical mastitis is the most economically important type of mastitis due to its higher prevalence and long term devastating effect as compared to clinical form of mastitis (Mungube et al., 2005). Due to this form of mastitis economic losses were valued in range of INR 21,677/- to INR 88,340/- per animal for a lactation period (Rathod et al., 2017). There are various methods for the detection of subclinical mastitis in milk such as California mastitis test (CMT), Somatic cell count (SCC), Electrical conductivity (EC) and biochemical and microbiological methods (Bastan et al., 1997; Lafi, 2006). For detection of subclinical mastitis, CMT could be considered as good and more accurate field test. CMT test showed higher prevalence rate than other test ( $\mathrm{pH}$, Chloride test \& WST) for subclinical mastitis. In and around the Nagpur region, the present study was investigate the prevalence of subclinical mastitis in cows by using field test i.e. California Mastitis Test.

\section{Materials and Methods}

\section{Selection of animals}

The cows were randomly selected from Cattle and Buffalo Breeding Farm, Nagpur
Veterinary College, Nagpur; Shukla Dairy Farm, Gorakshan Cattle Farm, Reddy Dairy Farm and other farms in and around Nagpur.

\section{Detection of subclinical mastitis}

A Total number of 601 milk samples from 151 cows were screened from in and around Nagpur region for the detection of subclinical mastitis by using field test i.e. Modified California Mastitis Test (Schalm and Noorlander, 1957).

The composition of MCMT reagent used was as follows:

Sodium lauryl sulphate (SDS) - 30 gm

Bromothymol blue - 5 gm

Distilled water up to - $100 \mathrm{ml}$

Required amount of milk from each quarter was taken into the respective four cups of CMT paddle. An equal amount of above CMT reagent was added in each cup and gently mixed by circular movement of paddle. After mixing, observed the any colour changes or formation of viscous gel and score was given to the sample.

\section{Grading of milk samples}

In present study, the result of Modified California Mastitis Test were scored as strong positive $(+++)$, distinct positive $(++)$, weak $(+)$ and negative (Normal) on the basis of gel formation or any colour change (Table 1).

\section{Results and Discussion}

In present study, a total 601 milk samples from 151 cows were screened by Modified California Mastitis Test for identification of subclinical mastitis. Out of 601 milk samples, about 200 milk samples were positive for 
subclinical mastitis while 390 milk samples observed to normal. The subclinical milk samples were classified into three groups as per their grading i.e ' + ' (weak positive), ' ++ ' (distinct positive) and ' +++ ' (strong positive). About 83 milk samples were observed as ' + ', 69 samples as ' ++ ' and 48 samples as ' +++ ' out of 200 subclinically affected milk samples. The overall animal wise and quarter wise prevalence of subclinical mastitis on the basis of Modified California Mastitis Test was $70.19 \%$ and $33.27 \%$, respectively. The quarter wise $34.94 \%$ milk samples were found positive for subclinical mastitis while $65.06 \%$ milk samples were found negative. From all samples $13.81 \%, 11.48 \%$ and $7.99 \%$ milk samples were observed for ' + ', ' ++ ' and '+++', respectively.

The result regarding animal wise prevalence of present study was slightly close to Swami et al., (2017) study. He studied total 60 dairy cattle from eight villages were selected on the basis of examination of udder and grading of Modified California Mastitis Test. Out of 60 cows 21 cows were positive and 39 cows were negative for subclinical mastitis. He found 35 percent prevalence of subclinical mastitis. However, Varatanovic et al., (2015) tested 1978 cows from total of 2150 cows by CMT and observed $56.02 \%$ (1108 cows) prevalence which was lower than the result of present study. The prevalence of subclinical mastitis in present study was lower than reported by Kurjogi and Kaliwal (2014). They concluded that Surf Field Mastitis Test (SFMT) was the most sensitive test which diagnosed highest number of SCM (46\%) and clinical mastitis (8\%) out of 263 cows. Similarly, Bonde et al., (2014) conducted study on 50 cows from which $20(40 \%)$ were negative for subclinical mastitis and $30(60 \%)$ cows were positive for CMT (+), CMT (++) and CMT (+++) subclinical mastitis which was nearer to the finding of present study. The quarter wise prevalence of subclinical mastitis in present study was closely related with Khan and Muhammad (2005) study who observed 36\% (out of 200, 72 quarters affected) prevalence, while Swami et al., (2017) reported $18.25 \%$ (45 quarters out of 240 quarters) quarter wise prevalence of subclinical mastitis in cow which is lower than the result of present study.

However, Varatanovic et al., (2015) concluded that CMT represents important diagnostic method in detection of subclinical mastitis in cows and out of 4432 quarters 2166 (48.87\%) were found positive to CMT which was higher than the result of present study. According to Bhutto et al., (2012), 507 (53\%) quarters out of 960 quarters reported as negative while 192 (20\%), 146 (15\%), 64 $(7 \%)$ and $51(5 \%)$ quarters as positive for subclinical mastitis detected by CMT. Present study result of different groups of subclinical mastitis was close to this result. In another study, Risvanli and Kalkan (2002) reported out of the 271 subclinical mastitis quarter $8.12 \%, 22.88 \%$ and $69.00 \%$ of quarter positive for CMT (+), CMT (++) and CMT (+++) respectively which was higher than that of present study. Similarly Kasikci et al., (2012) evaluated total 386 milk samples from quarters of 188 cows out of that $258(66.85 \%)$, $85(22.02 \%)$ and $43(11.13 \%)$ milk samples as CMT (+), CMT (++) and CMT (+++). Hassan and Yousif (2014) detected 105 (33.87\%) milk samples positive for subclinical mastitis by CMT cases out of total 310 milk samples. The result of Hassan and Yousif (2014) are closely related to prevalence of subclinical mastitis $33.27 \%$ while result of Kasikci et al., (2012) is higher than that of present study. The CMT test showed higher prevalence rate of subclinical mastitis than other test. For identification of subclinical mastitis CMT test was considered as good test and most accurate test diagnostic technique (Schalm et al., 1971). 
Table.1 Grading of milk samples

\begin{tabular}{|c|c|}
\hline CMT Score & Observations \\
\hline Negative & The mixture remains fluid without th1ickening or gel formation. \\
\hline Trace & $\begin{array}{l}\text { A slight slime formation is observed. } \\
\text { This reaction is most noticeable when the paddle is rocked from side } \\
\text { to side }\end{array}$ \\
\hline +/ Weak & $\begin{array}{l}\text { Distinct slime formation occurs immediately after mixing solutions. } \\
\text { This slime may dissipate over time. } \\
\text { When the paddle is swirled, fluid does not form a peripheral mass, and } \\
\text { the surface of solution does not become convex or "domed up." }\end{array}$ \\
\hline ++/Distinct positive & $\begin{array}{l}\text { Distinct slime formation occurs immediately after mixing solutions. } \\
\text { When the paddle is swirled the fluid forms a peripheral mass, and the } \\
\text { bottom of the cup is exposed. }\end{array}$ \\
\hline$+++/$ Strong positive & $\begin{array}{l}\text { Distinct slime formation occurs immediately after mixing solutions. } \\
\text { This slime may dissipate over time. } \\
\text { When the paddle is swirled the surface of the solution becomes convex } \\
\text { or domed up. }\end{array}$ \\
\hline
\end{tabular}

(California Mastitis Test was scored by Constable et al., 2017).

The variation of prevalence might be attributed to various factors i.e. age, breed, lactation period, season etc.

Kurjogi and Kaliwal (2014) also has reported that age, lactation period of the cow and environmental factors could be directly associated with the subclinical mastitis, whereas, clinical mastitis is more associated with the breed of the cow and environmental conditions.

Similarly, Ranjan et al., (2011) also has reported change in occurrence of bovine mastitis under different climatic conditions.

The present study was conducted at urban areas and during summer season by randomly selecting animal, which too might have resulted in the variations with the outcome of the other studies.

\section{Abbreviations}

CMT (California Mastitis Test), EC (Electrical conductivity), MCMT (Modified California
Mastitis Test), SDS (Sodium lauryl sulphate), SCC (Somatic cell count).

\section{References}

Abebe R., Hatiya, H., Abera, M., Megersa B., and Asmare, K., 2016. Bovine mastitis: prevalence, risk factors and isolation of Staphylococcus aureus in dairy herds at Hawassa milk shed, South Ethiopia. BMC Veterinary Research, 12: 270.

Bastan, A., Kaymaz, M., Fllldik, M., and Erunai, N., 1997. The use of electrical conductivity, Somatic Cell Count and California mastitis test in diagnosis of subclinical mastitis in dairy cows. Ankara Üniversitesi Veteriner Fakültesi Dergisi, 44: 1-6.

Bhikane, A. U., and Kawitkar S. B., 2016. Handbook for Veterinary Clinicians, $5^{\text {th }}$ ed. Krishna Prakashan, Udgir, 172173.

Bhutto, A. L., Murray R. D., and Woldehiwet, Z., 2012. California mastitis test scores as indicators of subclinical intra- 
mammary infections at the end of lactation in dairy cows. Research in Veterinary Science, 92: 13-17.

Bonde, S. W., Gaikwad, N. Z., Ravikanth, K., Thakur, A., and Maini, S., 2014. Effect of Herbal Topical Gel (Mastilep) application on the LDH activity and Total Immunoglobulin Levels in milk from cows suffering with Subclinical Mastitis. The Journal of Veterinary Science, Photon, 115: 370-376.

Constable, P. D., Hinchcliff, K. W., Done, S. H., and Grunberg, W., 2017. A textbook of the disease of Cattle, Horses, Sheep, Pigs and Goats 1: $11^{\text {th }}$ ed. ELSEVIER, 1904-1948.

Hassan, M. A., and Yousif, A. A., 2014. Evaluation of some biochemical indices in "milk whey" for diagnosis of subclinical mastitis caused by some Enterobacteriaceae family. Mirror of Research in Veterinary Sciences and Animals, 3(1): 1- 7.

Hillerton, J. E., 1998. Mastitis therapy is necessary for animal welfare. Bulletin of the IDF, 330: 4-5.

Kader, M. A., Samadand, M. A., and Saha, S., 2003. Influence of host level factors on prevalence and economics of subclinical mastitis in dairy cows in Bangladesh. Indian Journal of Dairy Science, 56: 235-240.

Kasikci, G., Cetin, O., Bingol, E. B., and Gunduz, M. C., 2012. Relations between electrical conductivity, somatic cell count, California mastitis test and some quality parameters in the diagnosis of subclinical mastitis in dairy cows. Turkish journal of veterinary and animal sciences, 36(1): 49-55.

Khan, A. Z., and Muhammad, G., 2005. Quarter-wise Comparative Prevalence of Mastitis in Buffaloes and Crossbred Cows. Pakistan Veterinary Journal, 25(1).
Kurjogi, M., and Kaliwal, B. B., 2014. Epidemiology of Bovine Mastitis in Cows of Dharwad District. International Scholarly Research Notices, 1-9.

Lafi, S.Q., 2006. Use of Somatic Cell Count and California Mastitis test results from udder halves milk samples to detect subclinical intramammary infection in Awassi sheep. Small Ruminant Research, 62: 83-86.

Mungube E. D., Tenghagen, B. A., Regassa, F., Kyule, M. N., Shiferaw, Y., Kassa, T., and Baumann, M P O., 2005. Reduced milk production in udder quarters with subclinical mastitis and associated economic losses in crossbred dairy cows in Ethiopia. Tropical Animal Health and Production, 37(6): 503-512.

Ranjan, R., Gupta, M. K., and Singh, K. K., 2011. Study of bovine mastitis in different climatic conditions in Jharkhand, India. Veterinary world, 4(5): 205-208.

Rathod, P., Shivamurty, V. and Desai, A. R., 2017. Economic losses due to Subclinical mastitis in dairy animals: A study in Bidar District of Karnataka. The Indian Journal of Veterinary Science and Biotechnology, 13(1): 3741.

Risvanl1, A., and Kalkan, C., 2002. The effect of age and breed on somatic cell count and microbiological isolation rates in milk of dairy cows with subclinical mastitis. Yuzuncu Yil Universitesi, Veteriner Fakultesi Dergisi, 13: 84-87. (in Turkish with summary in English).

Schalm, O. W., and Noorlander, D. O., 1957. Experiments and observations leading to developments of California Mastitis Test. Journal of the American Veterinary Medical Association, 130 (5): 199- 204. 
Schalm, O. W., Caroll, G., and Jain, N.C., 1971. Bovine Mastitis. Lea and Febiger Philadelphia Pa, USA, 95127.

Sharma, N., 2007. Alternative approach to control intramammary infection in dairy cows. A review. Asian Journal of Animal and Veterinary Adv ances, 2: 50-62.

Shukla, S.K., Dixit, V.P., Thapliyal, D.C., and Kumar, A., 1998. Bacteriological studies of mastitis in dairy cows.
Indian Journal of Veterinary Medicine, 22: 261-264.

Swami, S.V., Patiland, R.A., and Gadekar, S.D., 2017. Study on prevalence of Subclinical mastitis in dairy animals. Journal of entomology and zoology stu dies, 5(4): 1297-1300.

Varatanovic, N., Cengic, B., and Imsirevic, E., 2015. Research on subclinical mastitis and it's ethiological in different breeds of cow. Biotechnology in Animal Husbandry, 31(3): 365-374.

\section{How to cite this article:}

Lahamge, M. S., A. Thakre, S. W. Bonde, S. D. Borkar, A. P. Somkuwar and Patil, D. V. 2019. Prevalence of Subclinical Mastitis in Cows: In and Around Nagpur Region. Int.J.Curr.Microbiol.App.Sci. 8(12): 83-88. doi: https://doi.org/10.20546/ijcmas.2019.812.013 